Сергеј Мацура

Филолошки факултет у Београду

Катедра за англистику

sergej.macura@fil.bg.ac.rs
УДК 81`255.4:821.111.09(=163.41)

https://doi.org/10.18485/slavistika.2021.25.1.16

Оригинални научни рад примљено 27.03.2021.

прихваћено за штампу 17.06.2021.

\title{
ЈЕДАН ЕЛИОТОВ КВАРТЕТ У ПРЕВОДУ: „БЕРНТ НОРТОН“
}

У раду се анализира српски превод првог од Четири квартета Т.С. Елиота, „Бернт Нортон“, који је урадио Светозар Бркић 1966. године, и прва половина се односи на слој звучања, а друга на слој значења. Пошто је Елиот у оригиналу користио углавном акценатски стих, и то циљано полиметричан, приказују се примјери са прозодијским карактеристикама у оба језика, и на основу истраженог корпуса, види се задржавање истог броја акцената у већини српских стихова, као и нужно повећање броја слогова. Лексика у преводу је углавном прецизно нијансирана у зависности од атмосфере дате секције и расположења лирског субјекта, а синтагме и реченични обрти звуче врло природно у циљном језику. Рад пружа и неке примјере могућих побољшања на одређеним мјестима у којима се налазе неодговарајући преводилачки еквиваленти.

Кључне ријечи: Томас Стернс Елиот, „Бернт Нортон“, Светозар Бркић, акценатски стих, прозодија, полиметрија, дистрибуирани акценат, преводни еквивалент, вокабулар, динамични превод.

The paper analyses the Serbian translation of the first of T.S. Eliot's Four Quartets, "Burnt Norton", rendered by Svetozar Brkić in 1966, its first half concerning the layer of sound, and the second treating the layer of meaning. Since Eliot mostly employed accentual verse in the original, with polymetry in mind, examples are given with prosodic features in both languages, and based on the researched corpus, it is evident that the translation retains the same number of accents in most lines, and that it also necessarily increases the number of syllables. The lexis in translation is predominantly nuanced in an accurate way, depending on the atmosphere of the given sections and the lyrical subject's mood, and the phrases and sentence turns sound highly natural in the target language. The paper also offers some examples of possible improvements at certain places where there are inadequate translation equivalents.

Keywords: Thomas Stearns Eliot, "Burnt Norton", Svetozar Brkić, accentual verse, prosody, polymetry, hovering accent, translation equivalent, vocabulary, dynamic translation.

\section{1. Увод}

Томас Стернс Елиот (Thomas Stearns Eliot) оставио је недвосмислен самокритички суд, настао на основу година промишљања, да су Четири квартеma (Four Quartets) најбоље дјело које је написао (Eliot 1959: 63). Када се узме у обзир да је од објављивања првог до посљедњег прошло чак шест година, а до интервјуа са Дејвидом Холом (David Hall) још деценија и по, не можемо говорити о пренагљеном закључку или краткотрајном усхићењу писца над тек одштампаним текстом. У сржи овог пјесничког подухвата лежи напор да се људски живот представи као визија која се отима непосредном искуству, да се проникне у суштину ствари кроз ефемерни доживљај, а и сам наслов упућује на неке музичке аналогије (Кољевић 2002: 185). Четири пјесме имају упадљиве 
структурне сличности, пошто се свака састоји од пет дијелова, а унутар њих постоје секције, с тим да се четврти дио сваке састоји само од једне секције. Први дио, условно речено, има три секције, као сонатна форма у уводним ставовима класичне музике; други варира од лирских строфа до „прозаичне“ секције, као у „Литл Гидингу“ (“Little Gidding”, 1942), четвртом квартету; трећи је дискурзивно истраживање изложене теме; четврти је лирске природе и обично у строфама, и његове теме су најчешће експлицитно хришћанске; пети дио - по себи аномалан у класичним квартетима, осим код Бетовена - састоји се из двије секције и чини рекапитулацију цјелине (Kermode and Hollander 1973: 2003).

Иако Четири квартета чине јединствен низ, сваки је написан одвојено и може се читати као засебна пјесма. Сви су названи по неком мјесту, па први, „Бернт Нортон“ (“Burnt Norton”, 1936), носи име по ненастањеној сеоској кући у Глостерширу коју је Елиот посјетио заједно са пријатељицом Емили Хејл (Emily Hale) у љето 1934. године. Ист Коукер (“East Coker”, 1940) је село у Самерсету из кога је Елиотов предак Ендру емигрирао у Америку у XVII вијеку, Драј Салвејџиз (“Dry Salvages”, 1941) група је црних гранитних стијена код обале Масачусетса, а Литл Гидинг је село у Хантигдонширу у коме је у првој половини XVII вијека основана мала англиканска заједница, касније укинута у грађанском рату. На помало алузиван начин Елиот је покушао да опише и путању своје породичне историје и духовну линију коју из Енглеске баштине многи Американци.

Сваки квартет се бави неким видом односа времена и вјечности, значењем историје и постизањем тренутка безвременог увида у суштину људског постојања. Поред овога, подстакнут Хераклитовим фрагментима, Елиот медитира и о мировању и кретању, прошлости, садашњости и будућности, док прошарава текст повременим сликама плеса. Уза све наведене слојеве значења у квартетима, сваким доминирају мотиви одређеног годишњег доба, као и четири елемента предсократовске филозофије - управо по реду појављивања у дјелима: ваздуха, земље, воде и ватре. Имајући у виду густину значењског слоја у Четири квартета, као и акумулацију Елиотовог знања и прије и током година писања пјесама, сваки стих изискује велик опрез чак и при нормалном читању, а неупоредиво више при превођењу овог остварења на страни језик. Превод интегралног текста урадио је Светозар Бркић 1966. године, а објавила београдска „Просвета“ као прву књигу у едицији „Савремена светска поезија“. Не тако чест издавачки поступак штампе напоредног текста оригинала и превода омогућава изузетно лако праћење преводиочевог рада и провјеру квалитета у сваком тренутку који одговара читаоцу, а због велике дужине сва четири квартета укупно, овај рад ће се бавити анализом превода првог квартета, прво по особинама версификације, а затим по елементима значења, углавном лексике у синтаксичком контексту стихова на циљном језику.

Ради лакшег схватања какав је задатак стајао пред преводиоцем, даћемо мало детаљнији опис дијелова „Бернт Нортона“ и њихових секција, јер се унутар мањих цјелина често јављају различите дужине стиха, што изискује другачију реализацију превода, а нипошто уједначавање као у случају превода бланкверса или александринца. Први дио састоји се од 46 неримованих стихова, а уколико се може говорити о трима секцијама, оне захватају 14 и по стихова, 2 стиха 
„прелаза“ и 29 и по стихова у посљедњој. Други дио броји 43 стиха, од којих се првих петнаест римује по схеми $a b a c c b d c b b d e e e c$, затим слиједи секција од 20 и по стихова без риме, и на њу се надовезује такође неримована секција од 7 и по стихова. Трећи дио захвата 37 неримованих стихова, прва секција има 24 стиха, а друга 13, незнатно краћих по броју слогова. Четврти дио сложен је од 10 стихова промјењиве дужине са схемом риме aabacdecde, а пети има двије секције неримованих стихова - 22 и 18 понаособ, од којих су стихови у првој секцији дужи од стихова у другој. У пјесми од укупно 175 стихова налази се довољно различитих стиховних средстава да је назовемо полиметричном, као што је и за ауторову Пусту земљу (The Waste Land, 1922) врло проницљиво примијећено (Duffell 2012: 55-56). Стихови ће бити нумерисани, а и додатно означени страницом из Четири квартета (ЧК) на којој се налазе у „Просветином“ издању дјела.

\section{2. Анализа слоја звучања}

Први дио има стихове неједнаке дужине који у просјеку захватају 10.2 слога, што би одговарало бланкверсу када би стихови имали доминантно 10 слогова и понегдје 11, али је метрика далеко непредвидљивија, са готово константна 4 акцента и разноликим бројем слогова. Пошто се не ради о силабичко-тонској версификацији, не треба да тражимо релативну прозодијску проминентност која би била еквивалентна наглашености слога (Којен 1996: 33), него да означавамо тзв. тачке проминенције, акценатске контуре чија је природна функција концентрација на значење (Gates 1990: 575). Наглашени слог биће означен симболом „х““, а ненаглашени цртом, „-““ :

$\mathrm{x} \quad \mathrm{x}-\quad-\mathrm{x} \quad \mathrm{x}$

Time present and time past

$-\mathrm{x}-\mathrm{x}-\mathrm{x}-\mathrm{x} \quad \mathrm{x}-$

Are both perhaps present in time future,

$-\mathrm{X} \mathrm{X}-\mathrm{-}-\mathrm{-}$ X $\mathrm{X}$

And time future contained in time past. (1-3, ЧK 10)

Због сложеније морфологије српског језика, као и одсуства дифтонга, стихови у преводу нужно су дужи, и износе у просјеку 12.9 слогова:

$\mathrm{x}-\mathrm{x}--\mathrm{x}-\mathrm{x}-$

Време садашње и време прошло

$-\mathrm{x}-\mathrm{x}-\mathrm{x}--\mathrm{x}--\mathrm{x}--$

Су оба можда присутна у времену будућем,

$-\mathrm{x}-\mathrm{x}--\mathrm{x}---\mathrm{x}--\mathrm{x}-$

А време будуће садржано у времену прошлом. (ЧК 11)

Ови фактори утичу на то да трећи стих на српском врло лако добија додатни акценат, на глаголском придјеву трпном садржано, чији је број слого- 
ва двоструко већи него код оригиналног еквивалента. Преводилац се сусрео са тешким задатком да акценатски (тонски) стих који је релативно присутан у енглеском преобликује на одговарајући израз на српском, у коме овакав стих није непостојећи, али се појављује знатно рјеђе. Неки од примјера су поједине пјесме из Бећковићеве збирке Тако је говорио Матија (1965), као „Доста је било“: „Доста је било римованих песама! / Упрљајмо се речима као деца трешњама. / Разговарајмо о свему, а о свему једино и умем говорити“ (Бећковић 1999: 93). С друге стране, неке пјесме Стевана Раичковића граде се од јако кратких стихова, а опет акценатских по карактеристикама, као што је сонет „О врати се“, са три акцента и разним бројем слогова (Петров 2010: 45).

У првој секцији другог дијела јављају се римовани осмерци претежно јампског метра, а као својеврстан контрапункт, у другој секцији се налазе најдужи стихови у пјесми, од по 12.8 слогова, да би у трећој достизали у просјеку 10.7 слогова. Ово је почетак римоване формације:

Garlic and sapphires in the mud

Clot the bedded axle-tree.

The trilling wire in the blood

Sings below inveterate scars

Appeasing long forgotten wars. (47-51, $4 K 14)$

У фрагменту са схемом римовања аbacc други и четврти стих су са каталектичким трохејским завршецима, док се остали окончавају јампским стопама; додатни проблем ствара непотпуна рима, видљива у паровима mud - blood и scars - wars, које у преводу нема:

У блату сафири и лук

О осовину се лепе.

Дрхтава жица у крви

Пева под скорелом раном

Давнашњи смирујући рат. (

Успјех преводиоца свакако се види у уједначеном броју од 8 слогова у стиховима, иако њихове стопе варирају од чистог јамба у првом до дактила, којима почињу трећи, четврти и пети стих. На тај начин се губи могућност успостављања трохеја, али дикција остаје у равни Елиотове разуђене лексике (дрхтава, давнашњи). Одличан превод у метричком и римовном смислу јавља се мало ниже, у стиховима 58 и 59; тако је "And hear upon the sodden floor / Below, the boarhound and the boar” преведено као: „И чујемо по влажном тлу / Где вепар и пас, гонич му“ (ЧК 15). Први стих је правилан јампски тетраметар, док други почиње и завршава се јампском стопом, а између се налази комбинација пириха и спондеја, позната и као јонска стопа. 
У сљедећој секцији јављају се најдужи стихови читавог „Бернт Нортона“, и представљају видну супротност претходној дионици, како по слоговним, тако и по акценатским и римовним карактеристикама. У традицији енглеског језика оваквом формом вјешто се служио Волт Витмен у збирци Влати траве (Walt Whitman, Leaves of Grass), чији је текст прошириван од 1855. до 1892. године. У Витменовим стиховима веће дужине, који не подлијежу предодређеном метру, понекад се јавља једна акценатска цјелина на више ријечи у низу, а чак и лексичке ријечи губе свој примарни акценат:

$\mathrm{x}--\frac{\mathrm{x}}{-}-\mathrm{x}-\mathrm{x}$

Which of the young men does she like the best?

$-\quad \mathrm{x}--\frac{\mathrm{x}}{\mathrm{A}}-\mathrm{x}--\mathrm{x}$

Ah the homeliest of them is beautiful to her. (Whitman 1855, нав. y

Bradley 1939: 445)

У Елиотовом четвороакцентском стиху, барем у овој секцији II дијела, долази до сличних прозодијских појава, када се и именичке и глаголске синтагме доводе под један дистрибуирани акценат: ${ }^{1}$

$--\frac{\mathrm{x}}{-}-\frac{\mathrm{x}}{-}-\mathrm{x}-\mathrm{x}-$

At the still point of the turning world. Neither flesh nor fleshless;

$-\quad \mathrm{x}-\mathrm{x}_{-}-\mathrm{x}-\mathrm{x}-$

Neither from nor towards; at the still point, there the dance is,

$-\quad--\mathrm{x}-\mathrm{x}-\mathrm{x}_{\mathrm{x}} \mathrm{x}--$

But neither arrest nor movement. And do not call it fixity, $(62-64,4 K 14)$

Прегнантност енглеске морфологије и недостатак флективних наставака немају еквиваленте у српском језику, чија бујнија морфологија не дозвољава ни мањи број слогова ни дистрибуирани акценат као у оригиналу:

$-\mathrm{x}---\mathrm{x}----\mathrm{x}---\mathrm{x}--\mathrm{x}--$

У мирној тачки света који се креће. Нити месо нити не-месо:

- - $\mathrm{x}--\mathrm{x}-\mathrm{x}--\mathrm{x}-\mathrm{x}$

Нити од нити ка; у мирној тачки, ту је плес,

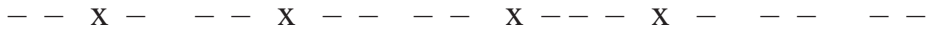

Нити застој нити кретање. И не називајмо учвршћеношћу то... (ЧК 15)

Синтагма “turning world” звучала би неприродно да је преведена као „окре$\hbar y \hbar u$ свет“, па је употребљена релативна клауза са адјективалном функцијом, а двосложна синтагма "still point” у преводу постаје „мирна тачка“ - сасвим одговарајуће рјешење, иако прозодијски не потпада под дистрибуирани акценат као оригинална. Иначе, просјек слогова ове секције у преводу износи 16.15 по

\footnotetext{
${ }^{1}$ Аутор користи прилику да се захвали др Горану Станићу и др Андреју Бјелаковићу на стручној помоћи из домена енглеске фонетике. Одговорност за евентуалне грешке сноси аутор.
} 
стиху, и уз честе велике варијације у дужини, сама каденца не прати довољно Елиотов равномјернији метрички израз. На неким мјестима се види и један акценат више у преводу, што је посљедица наведених морфолошких карактеристика српског језика. Један примјер биће довољан за илустрацију:

\section{$\mathrm{x}-\mathrm{x}-\mathrm{x}---\mathrm{x}$}

And I cannot say how long, for that is to place it in time. (69) $----\mathrm{x}--\mathrm{x}--\mathrm{x}---\mathrm{x}---\mathrm{x}-$ И не умем рећи, колико, јер значило би сместити то у време. (ЧК 17)

Оригиналних 15 слогова постало је 21 у преводу, који је семантички изразито прецизан, међутим, инхерентно компликована флексија у српском језику за резултат има већу дужину реченичних чланова; поред тога, показна замјеница that преведена је као „значило би“, да у самом стиху буде јасно да се односи на субјектову немогућност да просторно и временски одреди гдје се претходно налазио.

Трећи дио доноси краћи метар, у просјеку 9.88 слогова у првој и 9.38 слогова у другој секцији. Главна карактеристика овог дијела види се у томе што прва секција располаже већим бројем четвороакценатских стихова, а у другој свакако доминирају троакценатски. Осмотрићемо узорак из прве:

$\mathrm{x}-\mathrm{x}^{-}-\mathrm{x}-\mathrm{x}--\frac{\mathrm{x}}{\text { Men and bits of paper, whirled by the cold wind }}$

$-\quad-\quad x-x-x$

That blows before and after time,

$-\mathrm{x}-\mathrm{x}-\mathrm{x}-\mathrm{x}$

Wind in and out of unwholesome lungs

$\mathrm{x}-\mathrm{X}-\mathrm{x} \quad \mathrm{x}-$

Time before and time after. (104-107, $4 K 18)$

У преводу се број акцената врло досљедно чува, осим што на крају стиха 104 не налазимо једну акценатску цјелину, него усљед дужих ријечи у синтагми, читамо двије:

$$
\mathrm{x}---\mathrm{x}--\mathrm{x}----\mathrm{x}-\mathrm{x}-
$$

Људи и папирићи, усковитлани хладним ветром

$-\quad-\mathrm{x}-\mathrm{x}-\mathrm{x}--$

Што дува пре и после времена,

$$
\mathrm{x}----\mathrm{x}----\mathrm{x}--\mathrm{x}-
$$

Удахнутим и издахнутим из болесних плућа

$$
\mathrm{x}-\mathrm{x}-\mathrm{x}-\mathrm{x}-
$$

Време пре и време после. (ЧК 19)

У другој секцији, чији су стихови мало краћи, налазе се чести примјери постојања свега три лексичке ријечи по стиху, тако да нема неког мјеста ар- 
битрарном одређивању четвртог акцента, али то не значи да сви њени стихови садрже тачно три представника такозваних „отворених“ врста ријечи (у првом стиху и детерминатор all има акценат):

And destitution of all property,

Desiccation of the world of sense,

Evacuation of the world of fancy,

Inoperancy of the world of spirit; (118-121, ЧК 20)

Паралелизми из посљедња три стиха графички су далеко видљивији у оригиналу него у преводу, управо због разлике у аналитичком и синтетичком изражавању падешких односа у два језика, а акценти су распоређени на исте лексичке јединице у стиховима, и то условљава да је 12 од 13 ријечи у доњем цитату носилац акцента (све осим везника $u$ ):

И одсуство сваке својине,

Пресахлост света чула,

Испражњеност света маште,

Неделовање света духа; (ЧК 21)

Четврти дио својеврстан је кратки прелаз између два дужа и метрички равномјернија, и у њему дужина стиха варира од једног до четрнаест слогова; сходно томе, број акцената износи од један до шест:

Will $-\mathrm{x}-\mathrm{x}-\mathrm{x}--\mathrm{x}--$

Will the sunflower turn to us, will the clematis

$-\mathrm{x} x-\mathrm{x} x-\mathrm{x}^{-} \mathrm{x}$

Stray down, bend to us; tendril and spray

$\mathrm{x} \quad-\mathrm{x}$

Clutch and cling? (129-131, ЧК 20)

У преводу први стих садржи - ако се можемо послужити инструментима силабичко-тонске версификације - дактило-трохејски једанаестерац, само му именица павит, која га продужава на 13 слогова и прави опкорачење са наредним стихом, донекле ремети равнотежу започету цезуром иза шестог слога. Измјена мјеста предлошке синтагме и глагола савит онемогућује правилнији метар као „Пригнути и савит к нама“, што би од цијелог стиха 130 направило трохејски четрнаестерац. Трећи стих (131) има два акцента као и оригинал, а сам глагол држати не би био довољан еквивалент координираној синтагми "clutch and cling": 
- - $-\mathrm{x}-\mathrm{x}-\mathrm{x}-\mathrm{x}-$

Хоће л' се сунцокрет нагнути к нама, павит

$$
\mathrm{x}--\mathrm{x}-\mathrm{x}-\mathrm{x}---\mathrm{x}-
$$

Пригнути к нама, савит; стржаја и грана

$\mathrm{x}-\mathrm{x}-$

Држати сама? (ЧК 21)

Пети дио пјесме у првој секцији ствара готово истовјетну слику метра из првог дијела „Бернт Нортона“, са просјечном дужином од 10.1 слога по стиху и врло регуларном дистрибуцијом четири акцента, и понегдје три, ако су стихови краћи. Друга секција исписана је најкраћим метром у читавој пјесми, са просјечно 7.38 слогова по стиху, и једини лични глаголи унутар ње су be и rise:

$-\mathrm{x}-\mathrm{x}-\mathrm{x}-$

Desire itself is movement

$---\mathrm{x}-\mathrm{x}--$

Not in itself desirable;

$\mathrm{x}-\mathrm{x}-\mathrm{x}-$

Love is itself unmoving, (161-163, ЧK 22)

Превод готово да не одступа по броју слогова, а сви акценти налазе се на српским еквивалентима као и у изворнику:

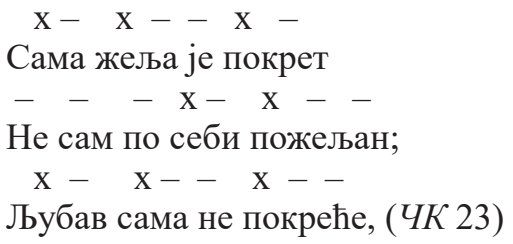

Мање присуство глагола у личном облику чини исказе криптичнијим и безвременијим, као својеврсну шару, чест симбол у квартету, а једна од посљедица је и нужно скраћење стихова због обиља неличних синтаксичких конструкција, као на самом крају пјесме: “Quick now, here, now, always - / Ridiculous the waste sad time / Stretching before and after" (173-175, ЧK 24).

\section{3. Анализа слоја значења}

Домен значења пред преводиоца поставља проблем првенствено у нијансама које ријечи исијавају у одговарајућем контексту; Елиот готово никада није раздвајао своју индивидуалну религиозност и вјерску праксу од општих истина које баштини читав људски род, а он их узима за теме у поезији. Изгледало би чак и неприродно да је овај пјесник писао поезију која се може искључиво схватати као утјеловљење формулаичних савјета који долазе из знаних и незнаних извора 
од источне до западне традиције кроз неколико миленијума стварања. Критичар Дејвид Муди (David Moody) сматра да је суштина Четири квартета у томе да положе ријечи на плећа. Њихов главни план је да тако употребљавају ријечи да би значиле нешто што је с ону страну ријечи, или да тако преобразе схватање свијета који се налази у њиховим ријечима да ће бити опажени као божанска Ријеч на дјелу (Moody 2005: 147). Тема покоравања времена кроз тренутке пројављивања вјечних истина и тема надвладавања ријечи у квартету су изведене заједно, пошто кроз ријечи ум задобија свијест која може трансцендовати вријеме, и наоко једноставне лексичке јединице често поред денотативног значења имају и дубље конотативно, углавном из религијског регистра. Тако се послије стиха 4, „Ако је читаво време вечно присутно“, наредни стих, “All time is unredeemable”, преводи као „Читаво време је неискупиво“, пошто је у ранијем стиху разријешен Августинов временски парадокс; поред тога, и жртва Исуса Христа фигурира као мотив у читавом даљем тексту. Сложеница rose garden (14) звучи природно и језгровито у српском деривираном облику ружичњак, без прибјегавања непотребним синтагмама као нпр. врт/башта са ружама. Замјеница they из стихова 23 и 30 односи се на присутности које се физички у башти не виде, него се могу наслутити по томе што их је природна околина свјесна (Blamires 1969: 11). Пошто је превод настао прије студије Харија Бламајреса (Harry Blamires) Word Unheard: A Guide through Eliot's Four Quartets, а и пошто се у српском непознати појам у множини означава чешће са они него оне, ово мјесто није било лак задатак за превод. Можда би конструкцију “Тhere they were” било ефикасније превести као „Тамо они беху“, а не „Они тамо беху“, али то је мањи камен спотицања него одређивање рода ових непознатих ентитета.

Када се и посјетиоци имања и метафизичке појавности крећу, они то раде “in a formal pattern” (31), што је на српском изведено као: „по нацрту тла“; субјект је сада свјестан тих појавности, које прихватају њега и он њих, док именица pattern значи и образаи и нащрт и план, са све видљивијим конотацијама вјечног у временском током Елиотове медитације. Превод нащрт тла звучи врло природно, као и круг зимзелена за box circle (32), с тим да енглеска синтагма открива вјештачку оивиченост круга, а оба геометријска лика имају исто средиште, у које долазе и човјек и неопипљиве присутности, па му се дешава откровење када то најмање очекује (Blamires 1969: 13). Када се деси тренутак присуства оностраних појавности, "the pool was filled with water out of sunlight" (35), иако у стварности воде нема; превод именице sunlight гласи прихватљиво: сунце, међутим, у пјесми се light у значењу и физичке и божанске свјетлости јавља на свакој страници.

Позабавићемо се даље неким примјерима у преводу који показују прецизно нијансирано значење, и можемо их сматрати успјелима, управо зато што преводилац није механички наметао еквиваленте из исте врсте ријечи или класе унутар врсте. Тако је "The trilling wire in the blood / Sings below inveterate scars" (4950) превео као „Дрхтава жища у крви / Пева под скорелом раном“, и видимо да би адјективал дрхтећа и множина ожиљци били мање природни у циљном језику. Сложеница boarhound (59) преведена је као пас гонич, што у недостатку дословног слагања ових морфема јасно означава функцију животиње из стиха. Beћ у стиху 60 поново се јавља вишезначна именица pattern, коју Бркић зна- 
лачки преводи као стаза - у контексту лова на вепрове, тешко је наћи ишта пунозначније а тачније. У сљедећој секцији јавља се неколико безглаголских стихова, да би изоморфно образовало „мирну тачку“ која се не креће, па у стиху 64 читамо: "But neither arrest nor movement”; превод гласи: „Нити застој нити кретање“, чиме се избјегава глаголска именица стајағе и њена конотација процеса који hе се у неком тренутку завршити. Близак паралелизам из стиха 66 “Neither ascent nor decline” преводи се као „Нити успон нити пад“, са антонимима који су фразеолошки прирођени српском језику, иако ascent овдје има и конотацију вазнесења. У стиху 71 синтагма "release from action and suffering" гласи „ослобођеност од делања и трпљења“, и одлично илуструје примарни задатак такозваног Пута афирмације у циљу потпуне спознаје (Blamires 1969: 14); ова именица користи се често и у преводима енглеских ренесансних писаца на српски, а јавља се на мноштву мјеста у српској књижевности XIX вијека. На ову конструкцију се наставља "release from the inner / And the outer compulsion" (71-72), што Бркић преводи као „ослобођеност од унутарње / И спољне принуде“ - док субјект медитира о успону и силаску на духовном путу, пожељно је да се темељне категорије искуства преводе изведеницама од основа које постоје колико и српски језик. На том фону налази се и еквивалент управног члана синтагме у стиху 78, “The resolution of its partial horror": тако читамо древну глаголску именицу са религијским конотацијама: „У разрешењу њеног делимичног ужаса“.

У трећем дијелу опет се јавља варијација на тему времена, са сложеним квалификацијама у наредној конструкцији: “Тime before and time after / In a dim light: neither daylight / Investing form with lucid stillness" (91-93), а вокабулар у преводу одаје вјештину налажења природног склада између придјева и именица у синтагмама: „Време пре и време после / У мутној светлости: нит у дневној светлости / Која заодева облик јасним мировањем.“" Придјеви нејасан и бистар/провидан не би се тако уклопили са именицама у контексту, а глагол заодевати поред физичке денотације садржи и конотацију спуштања божанске милости у виду давања чина особи. У стиху 99 види се антитеза пронађена можда прецизније него у самом оригиналу, "Neither plenitude nor vacancy. Only a flicker”, а превод гласи: „Ни пуноћа ни празнина. Само пламињање.“ Бркићево познавање вокабулара погодног за Елиотов пјеснички регистар јасно се види по глаголској именици пламињање, која и у контексту секције имплицира дуготрајније стање. У случају стиха 109, себи је дозволио проширење поимениченог придјева у именичку синтагму, што олакшава схватање овог компликованог текста: "the torpid / Driven on the wind”, а превод гласи: „равнодушни створови / Терани ветром“ - наравно, оваква продужавања стихова дешавају се само спорадично, у случајевима преке потребе. У сљедећој секцији налазе се већ наведене акценатски успјеле синтагме (стихови 119-121), а ништа мање нису прецизне ни у лексичком смислу: "Desiccation of the world of sense, / Evacuation of the world of fancy, / Inoperancy of the world of spirit." У преводу читамо: „Пресахлост света чула, / Испражњеност света маште, / Неделовање света духа“; чак и наставци за апстрактне именице -ion и -су имају еквиваленте у морфемама -ост и -ње (у случају глаголске именице), а можда најадекватније звучи пресахлост, веома у складу са темом исушеног духа трагаоца за суштином жи- 
вота. У четвртом дијелу постоји неколико упечатљиво конкретних и не тако честих израза за појаве из природе: clematis је naвum, tendril је cmpжајa, spray је грана, а yew је у преводу туја; сам одломак је кратко али темељно размишљање о томе како се елементи флоре односе према људима који почивају у земљи.

Посљедњи дио „Бернт Нортона“ не обилује вокабуларом чије примјере већ нисмо срели, али мјестимично се његова густина повећава, као у стиховима 149-151: "Words strain, / Crack and sometimes break, under the burden, / Under the tension, slip, slide, perish." На српски је вјерно пренесена нелагодност субјекта што нема контролу над оним што жели да изрази, када долази до флуктуације између мишљења и језика: „Речи се растежу, / Прскају и ломе се понекад, под теретом, / Под затегнутости, промаше, склизну, губе се." Умјешност преводиоца се види и у употреби личног глаголског облика тамо гдје је природнији као еквивалент за енглески партицип садашњи; тако за оригинал "Shrieking voices / Scolding, mocking, or merely chattering” (153-154) читамо превод: „Гласови што вриште, / Грде, ругају се или просто чаврљају“, док у непосредној близини “crying shadow” (157) постаје „плачна сенка“. Промишљен превод видимо и у парадоксу: "Desire itself is movement / Not in itself desirable" (161-162); основа и њен изведени облик без грешке су сачувани и у српском: „Сама жеља је покрет / Не сам по себи пожељан“.

На крају ћемо скренути пажњу на одређена преводилачка рјешења гдје су се омакла погрешна или неодговарајућа значења, што је посљедица сложености текста и недостатка критичких извора у времену превођења, а о сваком детаљу никад се не може водити довољно рачуна. Нека од мјеста су напросто наведена да би се видјела двосмисленост оригиналног значења, за које одговарајући превод нијанси оба значења не постоји. Тако стих 9 и половина стиха 10 гласе: "What might have been and what has been / Point to one end", а у преводу стоји: „Што је могло да буде и што је било / Показује један крај“ - у енглеском језику именица end може значити и ц̧иљ, сврxy, чешће него што се то налази у српском. Религијски тонови очитују се у Елиотовом оригиналу: "shall we follow / The deception of the thrush?” (21-22); српски превод: „хоћемо ли за / Опсеном дрозда?““ звучи прегнантно без главног глагола, али се конотација сљедбеништва не види. Можемо се питати да ли је pool из стиха 34 и даље адекватно преведен као рибњак, јер се налази у господској башти, а с друге стране, алтернатива језерие можда не дочарава неку бетонирану увалу мањих димензија. Озбиљнија грешка налази се у стиховима 40 и 41: "for the leaves were full of children, / Hidden excitedly, containing laughter.” Умјесто рјешења ,jер лишће беше пуно деце, / Узбудљиво скривене, и пуне смеха“, требало би да стоји: „Узбуђено скривене, како задржавају/обуздавају смех.“ Тешко је схватљиво, осим као превид усљед умора, зашто је Бркић превео lymph у стиху 53 као крв, када је то лимфа. Могуће је да га је занијела именица крв која се јавља нетом раније, у стиху 49. У стиху 79 јавља се “enchainment of past and future”, а у преводу стоји: „,повезаност прошлости и будућности“, што је прихватљиво, само што у туробном контексту проласка душе кроз мучна стања (принуду, ужас и слично) прикладније звучи увезаност, која имплицира непријатну и детерминисану сталну везу тих временских димензија. Имајући у виду да се простор у III дијелу односи на лондонски метро (Kermode and Hollander 1973: 2002), чија атмосфера није ни 
пријатна ни природна, именица из стиха 90 - "Here is a place of disaffection" („Ово је место отпадништва“) - боље би се уклапала у контекст када би гласила незадовољство. Мало даље, стих 98 за affection наводи љубав, која нема изведеницу у горњем стиху, па ни превод ни предлог не постижу однос као affection/ disaffection. У слици која личи на гужву преко мостова Лондона из Пусте земље, види се "Eructation of unhealthy souls” (108), преведено као „Подригивање нездравих душа“. Ове душе, односно измождене људе у безумној трци за зарадом, изригава огромни град у изблиједјели ваздух, и боље је то превести као избљувавање. У стиху 113, синтагма "in this twittering world" на српском је срочена „У овом узврпољеном свету“, док ти гласови који ремете тишину треба да буду брбљави, ћурликави или ивркутави, ближи изворном значењу. На самом крају овог дијела (124-125), јавља се двојако значење свјетских путева - “while the world moves / In appetency, on its metalled ways” у преводу гласи „док се свет креће / Са жудњом, насутим путевима“. Слика дочарава погрешну вјеру у линеарни напредак у материјалном смислу, а осим ауто-путева, конотирају се и пруге, на којима човјек нема слободу ни да скреће (Blamires 1969: 30-31). У посљедњем дијелу квартета можемо издвојити двије именичке синтагме које на српском не одговарају сасвим првобитним појмовима: прва је "Chinese jar" (142), на српском „кинески крчаг“, мада би ближе стварности било „кинески $\hbar y n “$, а друга је "in the figure of the ten stairs” (160). Превод гласи: „у фигури десет степеништа". Ово је у ствари алузија на теологију Светог Јована од Крста, који користи слику успињања по десет степеника да би објаснио дисциплину медитације (Blamires 1969: 40). Парадокс индивидуалног кретања које се завршава општим некретањем карактерише цијели квартет, тако да не чуди што се ова референца налази при самом завршетку Елиотове поеме.

Укратко, Светозар Бркић је врло успјешно обавио тежак задатак превода „Бернт Нортона“ и у версификацијском и у лексичком смислу: број акцената из стиха који није прирођен српском језику успио је да задржи у огромној већини стихова, а и тамо гдје има силабичких елемената био је вјеран оригиналу. Овај текст у преводу красе течан, неискварен језик и кретање кроз разне регистре, а ако медитативни субјект пролази кроз високе или ниске сфере духовног искуства, преводилац сходно томе употребљава лепршавији или тмурнији вокабулар, и уз евентуална побољшања риме и неке значењске исправке, број замјерки које би му се могле упутити свакако није висок.

\section{Цитирана литература}

Бећковић, Матија. Од-до: изабране и нове песме. Београд: Задужбина Десанке Максимовић, Народна библиотека Србије, Српска књижевна задруга, 1999.

[Bećković, Matija. Od-do: izabrane i nove pesme. Beograd: Zadužbina Desanke Maksimović, Narodna biblioteka Srbije, Srpska književna zadruga, 1999]

Елиот, Томас Стернс. Четири квартета. Прев. Светозар Бркић. Београд: Просвета, 1966.

[Eliot, Tomas Sterns. Četiri kvarteta. Prev. Svetozar Brkić. Beograd: Prosveta, 1966]

Којен, Леон. Студије о српском стиху. Сремски Карловци, Нови Сад: Издавачка књижарница Зорана Стојановића, 1996. 
[Kojen, Leon. Studije o srpskom stihu. Sremski Karlovci, Novi Sad: Izdavačka knjižarnica Zorana Stojanovića, 1996]

Кољевић, Светозар. Енглески песници двадесетог века (1914-1980). Београд: Завод за уџбенике и наставна средства, 2002.

[Koljević, Svetozar. Engleski pesnici dvadesetog veka (1914-1980). Beograd: Zavod za udžbenike i nastavna sredstva, 2002]

Петров, Александар. „Три тезе о поезији Стевана Раичковића“. [У:] Делић, Јован (ур.) Поетика Стевана Раичковића. Београд, Требиње: Институт за књижевност и уметност, Учитељски факултет, Дучићеве вечери поезије, 2010, 19-49.

[Petrov, Aleksandar. „Tri teze o poeziji Stevana Raičkovića“. [U:] Delić, Jovan (ur.) Poetika Stevana Raičkovića. Beograd, Trebinje: Institut za književnost i umetnost, Učiteljski fakultet, Dučićeve večeri poezije, 2010, 19-49]

Blamires, Harry. Word Unheard: A Guide through Eliot's Four Quartets. London: Methuen \& Co., 1969.

Bradley, Sculley. "The Fundamental Metrical Principle in Whitman's Poetry". American Literature 4, 1939: 437-459.

Duffell, Martin J. "Design and Rhythm in T. S. Eliot's The Waste Land". Rhythmica: revista española de métrica comparada 1, 2012: 45-76.

Eliot, Thomas Stearns. "The Art of Poetry 1: T.S. Eliot”. Paris Review 1-2, 1959: 47-70.

Gates, Rosemary L. “T. S. Eliot's Prosody and the Free Verse Tradition: Restricting Whitman's 'Free Growth of Metrical Laws"'. Poetics Today 3, 1990: 547-578.

Kermode, Frank, John Hollander. "Introduction to 'Little Gidding"”. [In:] Kermode, Frank, John Hollander (gen. eds.) The Oxford Anthology of English Literature. New York, London, Toronto: Oxford University Press, 1973, 2002-2004.

Moody, A. David. "Four Quartets: Music, Word, Meaning and Value". [In:] Moody, A. David (ed.) The Cambridge Companion to T.S. Eliot. Cambridge: Cambridge University Press, 2005, 142-157.

Sergej Macura

\section{A T.S. ELIOT QUARTET IN TRANSLATION: "BURNT NORTON"}

\section{Summary}

The paper features an analysis of the Serbian translation of T.S. Eliot's quartet "Burnt Norton", the first poem published in the series (1936). This demanding text was translated by Svetozar Brkić and printed by the Prosveta Publishing Company in Belgrade in 1966. The first level of analysis concentrates on the aspects of sound and gives comparisons between the elements of English and Serbian versification and prosody: the major task that the translator had to accomplish consisted in following Eliot's accentual verse, much more frequent in English than in Serbian poetry. In addition, Eliot's polymetric variations necessitated shifts from the dominant four-accent lines to those with three accents, and there were two brief sections with elaborate rhyming schemes. Brkić tried to keep up with the demanding compression of English phonetics and morphology, extending the shortest lines by one or two syllables, and extending the longer ones by as many as four or five. $\mathrm{He}$ retained almost all the accented words in the poem, and due to the inherently lengthier construc- 
tions in Serbian, some lines contain one accent too many, and the hovering English accent enables the original to make one unit of two lexical words, which is not the case with the Serbian equivalents. The second level of analysis discusses the meanings of numerous words or phrases in this complex text: since the lyrical subject meditates on the soul's ascent and descent, time and eternity, those different moods were translated with carefully nuanced words from diverse registers. The translator also formed phrases and sentences with much skill, and certain places sound like genuine Serbian poetry of the time, enhancing the fullness of the reading experience. The paper ends by suggesting several corrections in the translation, where the Serbian equivalents were chosen with a lower precision.

Keywords: Thomas Stearns Eliot, "Burnt Norton", Svetozar Brkić, accentual verse, prosody, polymetry, hovering accent, translation equivalent, vocabulary, dynamic translation. 